\title{
The Clustering of Provinces in Indonesia by The Economic Impact of Covid-19 using Cluster Analysis *
}

\author{
Pengelompokkan Provinsi di Indonesia dengan Ekonomi Terdampak \\ Covid-19 Menggunakan Analisis Cluster
}

\author{
Zerlita Fahdha Pusdiktasari ${ }^{1 \ddagger}$, Widiarni Ginta Sasmita ${ }^{2}$, Wulaida \\ Rizky Fitrilia ${ }^{3}$, Rahma Fitriani ${ }^{4}$, and Suci Astutik ${ }^{5}$ \\ 1,2,3,4,5 Jurusan Statistika, Universitas Brawijaya, Indonesia \\ ${ }^{\ddagger}$ corresponding author: zerlitafahdha@student.ub.ac.id
}

Copyright @ 2021 Zerlita Fahdha Pusdiktasari, Widiarni Ginta Sasmita, Wulaida Rizky Fitrilia, Rahma Fitriani, and Suci Astutik. This is an open-access article distributed under the Creative Commons Attribution License, which permits unrestricted use, distribution, and reproduction in any medium, provided the original work is properly cited.

\begin{abstract}
The Covid-19 pandemic has hit Indonesia since March 2020. Several policies have been issued by the Indonesian government to reduce the level of the spread of Covid19. This policy has an impact on various fields of life, especially the economic sector in various sectors. This study was conducted to analyze the grouping of provinces whose economies are at risk of being affected by Covid-19 based on various economic sectors, namely the unemployment rate, the percentage of poor people, the provincial minimum wage, and the occupancy rate of hotels using cluster analysis. Cluster analysis was performed using several hierarchical methods, namely Simple, Complete, Average, and Centroid Linkage and Ward. The Cophenetic correlation coefficient ( $\mathrm{rCoph}$ ) was used to determine the best method, while the number of clusters was determined based on the Dunn, Connectivity, and Silhouette indexes. The analysis result shows that Average Linkage is the best method with two clusters. The first cluster consists of all provinces in Indonesia except Papua, whose economy is highly at risk of being affected by Covid-19, characterized by a low percentage of the poor and a low provincial minimum wage, as well as high levels of open unemployment and hotel occupancy rates. Meanwhile, the second cluster consists of the Province of Papua, which is an economic group with a low risk of being affected by Covid-19. By looking at the impact of the Covid-19 disaster, the government can make recovery efforts and generalize economic recovery policies due to Covid-19 which have an impact on the economy of almost all provinces in Indonesia.
\end{abstract}

Keywords: cluster analysis, Covid-19, economics, policy.

\footnotetext{
* Received: Des 2020; Reviewed: Jan 2021; Published: Mar 2021
} 


\section{Pendahuluan}

Pandemi Covid-19 (corona virus disease 2019) melanda dunia sejak Desember 2019 yang berawal dari Kota Wuhan, China. Di Indonesia, kasus positif pertama ditemukan pada tanggal 2 Maret 2020. Kemudian sejak itu, kasus positif corona di Indonesia meningkat dengan pesat. Hingga November 2020, total kasus positif Covid-19 yang dilaporkan di Indonesia mencapai 471.000 kasus dengan 392.000 pasien sembuh dan 15.296 pasien dinyatakan meninggal (Our World in Data, 2020).

Banyak usaha yang telah ditempuh oleh pemerintah dalam upaya untuk mengurangi tingkat penyebaran virus corona atau disebut dengan istilah "flatten the curve" oleh Steven (2020). Salah satunya yaitu kebijakan pemberlakukan Pembatasan Sosial Berskala Besar (PSBB) yang dikeluarkan pemerintah sejak tanggal 31 Maret 2020. Melalui Peraturan Menteri Kesehatan No. 9 Tahun 2020 tentang Pedoman Percepatan Penanganan Covid-19, ditetapkan beberapa kebijakan PSBB antara lain: 1) Peliburan sekolah dan tempat kerja; 2) Pembatasan kegiatan keagamaan; 3) Pembatasan kegiatan di tempat/ fasilitas umum; 4) Pembatasan kegiatan sosial budaya; 5) Pembatasan moda transportasi; 6) Pembatasan kegiatan lainnya terkait aspek pertahanan dan keamanan (KemLu, 2020).

Kebijakan-kebijakan yang dikeluarkan oleh pemerintah tersebut berdampak pada berbagai bidang kehidupan di Indonesia, khususnya bidang ekonomi. Akibat adanya pembatasan aktivitas sosial, perekonomian di Indonesia semakin melemah. Sektor informal seperti ojek online, pedagang kaki lima, UMKM, dan pusat perdagangan menjadi sepi pengunjung. Tak hanya itu, sektor pariwisata juga mengalami penurunan setelah pemerintah menutup tempat wisata dan transportasi lintas daerah (Syafrida \& Hartati, 2020). Pada sektor industri sendiri, pemotongan jam kerja mulai diterapkan dan beberapa diantaranya menggunakan sistem shift yang kemudian berdampak pada banyaknya pengurangan tenaga kerja dengan alasan efisiensi karena produksi juga terpaksa dibatasi. Hal inilah yang memicu peningkatan tingkat pengangguran dan kemiskinan di Indonesia.

Perekonomian negara tidak dapat terus menerus berada pada kondisi seperti sekarang ini. Perlu adanya tindakan pemulihan agar roda ekonomi negara dapat berputar sebagaimana mestinya. Oleh karena itu, penelitian ini dilakukan untuk mendukung tindakan pemulihan perekonomian bagi pemerintah. Melalui penelitian ini, daerah-daerah di Indonesia akan dibagi menjadi beberapa kelompok daerah berdasarkan tingkat keparahan dampak Covid-19 terhadap perekonomiannya. Variabel ekonomi dipilih berdasarkan keterkaitannya dengan kebijakan pemerintah dalam menghadapi Covid-19.

Penelitian yang dilakukan oleh Novriansyah (2018) menunjukkan bahwa tingkat pengangguran dan kemiskinan memberikan pengaruh terhadap pertumbuhan ekonomi; lalu Imanto dkk (2020) juga membuktikan bahwa tingkat pengangguran dan kemiskinan sangat mempengaruhi pertumbuhan ekonomi daerah; Julianto \& Suparno (2016) menunjukkan upah minimum daerah memberikan pengaruh signifikan terhadap pertumbuhan ekonomi; serta Suastika \& Yasa (2017) memaparkan bahwa tingkat hunian hotel secara signifikan mempengaruhi pendapat asli daerah. Keempat variabel ekonomi ini nantinya akan digunakan untuk melihat kondisi perekonomian provinsi di Indonesia.

Penelitian yang berkaitan dengan dampak Covid-19 terhadap perekonomian juga 
telah banyak dilakukan. Beberapa di antaranya; Engkus dkk (2020) mengkaji kebijakan pemerintah dalam menanggulangi Covid-19 dan dampaknya terhadap sosial ekonomi; lalu Kurniawansyah dkk (2020) menggunakan metode deskriptif untuk menganalisis konsep kebijakan pemerintah terhadap eksternalitas ekonomi Covid-19; Hardilawati (2020) mengeksplorasi strategi yang dapat dilakukan UMKM untuk mempertahankan usahanya; dan Ulya (2020) menggunakan metode studi literatur untuk menganalisis alternatif strategi ekonomi pada kawasan agropolitan. Sebagian besar dari penelitian tersebut dilakukan menggunakan metode kualitatif seperti deskriptif dan kajian teori ekonomi/ kebijakan, serta belum menyentuh usaha pemulihan ekonomi.

Penelitian ini berkontribusi untuk memberikan kajian berdasarkan analisis kuantitatif, yaitu analisis cluster. Analisis cluster digunakan untuk mengetahui kelompok provinsi yang perekonomiannya beresiko terdampak Covid-19. Berbeda dengan analisis multivariat lain yang memerlukan asumsi normalitas, analisis cluster hanya memiliki dua asumsi untuk dipenuhi yaitu kecukupan sampel dan tidak adanya multikolinieritas (Hair dkk., 2010). Hasil penelitian ini diharapkan dapat dijadikan sebagai acuan dan pertimbangan bagi pemerintah dalam merumuskan kebijakan pemulihan kondisi ekonomi yang terdampak Covid-19 agar tepat sasaran dan sesuai dengan kondisi ekonomi daerah yang ditargetkan.

\section{Metodologi}

\subsection{Bahan dan Data}

Penelitian ini menggunakan data yang diperoleh dari publikasi Badan Pusat Statistika (BPS) yang berjudul "Perkembangan Beberapa Indikator Utama Sosial -Ekonomi Indonesia" pada Tahun 2020 Semester 1. Variabel ekonomi digunakan ialah Persentase Penduduk Miskin (PPM) dalam persen, Tingkat Pengangguran Terbuka (TPT) dalam persen, Upah Minimum Provinsi (UMP) dalam rupiah, dan Tingkat Penghunian Hotel (TPH) dalam persen. Unit sampel pada penelitian ini menggunakan provinsi yang ada di Indonesia, sebanyak 34 provinsi. Prosedur analisis data dilakukan menggunakan bantuan Microsoft Excel dan software R.3.5.2.

\subsection{Metode Penelitian}

Analisis cluster adalah metode analisis peubah ganda yang bertujuan untuk mengelompokkan $n$ satuan observasi ke dalam $k$ kelompok, dimana $(k<n)$, dilihat dari $p$ peubah (Mattjik \& Sumertajaya, 2011). Cluster dikatakan baik jika bersifat homogenitas (kesamaan) tinggi antar-anggotanya dalam satu cluster (within-cluster) dan bersifat heterogenitas (perbedaan) yang tinggi antar cluster. Sebelum dikelompokkan, terlebih dahulu perlu dilakukan pengukuran jarak antar objek pengamatan, dimana pada penelitian ini digunakan jarak Euclidean. Jarak Euclidean mampu melakukan pengelompokan suatu data lebih mudah dengan menggunakan pendekatan matriks dan jarak antar kelompok dapat diketahui dengan jelas selain itu jarak Euclidean hubungan antar peubah diabaikan karena tidak menggunakan unsur keragaman. Menurut Johnson \& Wichern (2007) jarak Euclidean merupakan tipe yang paling umum dalam analisis cluster untuk mengukur jarak dari objek data ke pusat 
cluster. Jarak Euclidean untuk dua objek dengan $p$ variabel dapat dituliskan pada persamaan 2.1. Diketahui $\boldsymbol{x}^{\prime}=\left[x_{1}, x_{2}, \ldots, x_{p}\right]$ dan $\boldsymbol{y}^{\prime}=\left[y_{1}, y_{2}, \ldots, y_{p}\right]$ maka,

$$
\begin{aligned}
d(\boldsymbol{x}, \boldsymbol{y}) & =\sqrt{\left(x_{1}-y_{1}\right)^{2}+\left(x_{2}-y_{2}\right)^{2}+\cdots+\left(x_{p}-y_{p}\right)^{2}} \\
& =\sqrt{(\boldsymbol{x}-\boldsymbol{y})^{\prime}(\boldsymbol{x}-\boldsymbol{y})}
\end{aligned}
$$

Dengan:

$d(\boldsymbol{x}, \boldsymbol{y})$ : jarak euclidean antara objek ke- $x$ dengan objek ke- $y$

$x_{i} \quad$ : variabel ke $i$ objek ke- $x, i=1, \ldots, p$

$y_{i} \quad:$ variabel ke $i$ objek ke- $y, i=1, \ldots, p$

Selanjutnya, dalam mengelompokkan objek pengamatan terdapat beberapa metode yang dapat digunakan. Metode cluster terdiri dari dua metode, yaitu metode metode non-hierarki dan hierarki. Perbedaan dari kedua metode tersebut terletak pada penentuan banyak cluster yang akan dibentuk. Pada metode hierarki, penentuan banyaknya cluster dilakukan melalui proses pengelompokan secara bertahap hingga membentuk suatu tingkatan/ tahapan. Sedangkan pada metode non-hierarki, banyaknya cluster ditentukan terlebih dahulu secara manual. Beberapa metode cluster yang tergolong metode hierarki sebagai berikut.

\section{a. Metode Single Linkage}

Dalam melihat jarak antar dua cluster yang kemudian memilih jarak paling dekat atau bersifat tetangga dekat (nearest neigbour rule). Langkah-langkah menggunakan metode single linkage (Johnson \& Wichern, 2007):

a) Menghitung jarak euclidean pada masing masing sub sampel dengan sub sampel lain.

b) Memilih jarak minimum antar sub sampel dalam $D=\{$ dij $\}$

c) Menghitung jarak antara cluster yang telah dibentuk dengan objek berbeda.

d) Dari algoritma di atas jarak antara sub sampel (IJ) dan cluster $\mathrm{K}$ yang lain dihitung dengan persamaan 2.2.

dengan

$$
d_{(I J) k}=\min \left(d_{I K}, d_{J K}\right)
$$

$d_{(I J) k} \quad$ : jarak antara sub sampel (IJ) dan cluster K

$d_{I K} \quad$ : jarak sub sampel I dan cluster $\mathrm{K}$

$d_{J K}$ : jarak sub sampel $\mathrm{J}$ dan cluster $\mathrm{K}$

Dalam hal ini besaran $d_{I K}$ dan $d_{J K}$ masing-masing merupakan jarak terpendek antara cluster I dan $\mathrm{K}$ dan juga cluster J dan $\mathrm{K}$.

\section{b. Metode Complete linkage}

Pada metode complete linkage, menentukan jarak antar cluster menggunakan jarak terjauh (farthest-neighbour) antara dua obyek dalam cluster yang berbeda (Johnson \& Wichern, 2007). Rumus jarak dapat ditulis pada persamaan 2.3.

Dengan:

$$
d_{(I J) k}=\max \left(d_{I K}, d_{J K}\right)
$$

$d_{(I J) k} \quad$ : jarak-jarak antara sub sampel (IJ) dan cluster $\mathrm{K}$

$d_{I K} \quad$ : jarak sub sampel I dan cluster $\mathrm{K}$

$d_{J K} \quad$ : jarak sub sampel $\mathrm{J}$ dan cluster $\mathrm{K}$

\section{c. Metode Average Linkage}

Jarak antar cluster diasumsikan sebagai jarak rata-rata antara semua anggota 
dalam satu cluster dengan semua anggota cluster. Rumus jarak dapat ditulis pada persamaan 2.4.

Dengan:

$$
d_{(I J) k}=\frac{\sum_{I} \Sigma_{J} d_{I J}}{N_{I J} N_{K}}
$$

$d_{(I J) K}:$ jarak-jarak antara sub sampel (IJ) dan cluster $\mathrm{K}$

$d_{I J}$ : Jarak antara sub sampel I pada cluster K dan sub sampel J pada cluster K

$N_{I J}$ : Banyak item pada cluster (IJ)

$N_{K}$ : Banyak item pada cluster (IJ) dan $\mathrm{K}$

\section{d. Metode Centroid}

Metode centroid merupakan rata-rata dari semua obyek dalam cluster. jarak antar centroid adalah jarak antar cluster. Centrois cluster baru yang terbentuk didapat dengan menggunakan rumus 2.5 .

Dengan:

$$
\bar{x}=\frac{\left(N_{1} \bar{x}_{1}+N_{2} \bar{x}_{2}\right)}{N_{1}+N_{2}}
$$

$N_{1}, N_{2}$ : banyaknya objek

\section{e. Metode Ward}

Metode Ward didasari oleh hilangnya informasi yang disebabkan oleh penggabungan obyek menjadi cluster. Metode ini diukur dengan SSE (Sum Square Error) sebagai fungsi obyektif (Johnson \& Wichern, 2007). Tujuan Metode Ward meminimumkan ragam dalam cluster dan memaksimalkan ragam antar objek di cluster lainnya. Nilai SSE (Sum Square Error) untuk cluster dengan anggota satu objek atau satu item saja adalah bernilai nol. Jika terdapat $\mathrm{N}$ item yang dikelompokkan menjadi satu cluster, maka dapat diketahui perhitungan nilai SSE yang tersaji pada persamaan 2.6.

Dengan:

$$
S S E=\sum_{i=1}^{N}\left(\boldsymbol{X}_{\boldsymbol{i}}-\overline{\boldsymbol{X}}\right)^{\prime}\left(\boldsymbol{X}_{\boldsymbol{i}}-\overline{\boldsymbol{X}}\right)
$$

$\boldsymbol{X}$ : vektor kolom dari objek ke- $i$, dimana $i=1,2,3, \ldots, \mathrm{N}$

$\overline{\boldsymbol{X}}$ : vektor kolom rata-rata seluruh objek

$\mathrm{N}$ : banyak objek dalam cluster yang terbentuk

Menurut Hair dkk (2010) validitas digunakan oleh peneliti untuk mengetahui apakah hasil kelompok cluster yang terbentuk mampu menjelaskan dan mewakili populasi secara umum. Dengan validasi dapat membantu memecahkan permasalahan dalam menentukan banyak kelompok yang optimal. Terdapat beberapa indeks yang digunakan dalam pengelompokan, antara lain sebagai berikut.

\section{a. Indeks Dunn (D)}

Indeks validasi Dunn dilambangkan dengan $D$ dihitung dengan rumus yang tersaji pada persamaan 2.7.

Dengan:

$$
D=\min _{1 \leq i \leq n}\left\{\min _{1 \leq k \leq n, i \neq j}\left\{\frac{d\left(c_{i}, c_{j}\right)}{\max _{1 \leq k \leq n}\left(d^{\prime}\left(c_{k}\right)\right)}\right\}\right\}
$$

D : indeks Dunn 
$d\left(c_{i}, c_{j}\right)$ : jarak antar kelompok $c_{i}$ dan $c_{j}$

$d^{\prime}\left(c_{k}\right) \quad$ : jarak dalam kelompok $c_{k}$

Semakin besar nilai indeks Dunn maka diindikasi banyak cluster yang terbentuk lebih baik (Kovács et al., 2006).

\section{b. Indeks Connectivity}

Indeks validasi Connectivity dilambangkan dengan Conn dengan rumus yang tersaji pada persamaan 2.8.

Dengan:

$$
\text { Conn }=\sum_{i=1}^{N} \sum_{j=1}^{L} X_{i, n n_{i(j)}}
$$

Conn : indeks Connectivity

$n n_{i(j)} \quad$ : pengamatan tetangga terdekat (nearest neighbour) dari data ke-j ke data ke- $i$, jika dalam satu cluster bernilai 0 (nol) dan jika berbeda, bernilai $1 / j$.

$\mathrm{N} \quad$ : banyak pengamatan

L $\quad$ : banyak cluster

Semakin kecil nilai Indeks Connectivity maka diindikasi menunjukkan banyak cluster yang terbentuk lebih baik atau optimal (Halim \& Widodo, 2017).

\section{c. Indeks Global Silhouette}

Indeks Validitas Global Silhouette digunakan untuk menghitung rata-rata dari titik yang ada pada himpunan data. Metode ini dapat digunakan sebagai validasi pada seluruh data, baik yang bersifat tunggal atau keseluruhan cluster. Indeks Global Silhouette merupakan metode yang paling umum untuk memvalidasi cluster yang menghubungkan separasi dan kohesi. Rumus perhitungan indeks Silhouette $S(i)$ tersaji pada persamaan 2.9 dan 2.10.

$$
\begin{gathered}
S_{i}=\frac{b_{i}-a_{i}}{\max \left[b_{i}, a_{i}\right]} \\
S C=\frac{\sum_{i=1}^{n} s_{i}}{n}
\end{gathered}
$$

Dengan:

$S_{i} \quad$ : indeks Silhouette pada objek ke- $i$, dengan $i=1,2, \ldots, n$

$a_{i} \quad$ : rata-rata kemiripan antara objek ke- $i$ dengan objek lain di dalam clustemya

$b_{i} \quad$ : nilai minimum dari rata-rata kemiripan antara objek ke- $i$ dengan objek lain di luar clustemya

SC : rata-rata rentang nilai indeks Silhouette

Semakin besar rata-rata rentang nilai indeks Silhouette dari seluruh objek dalam suatu cluster $(S C)$ menunjukkan banyak kelompok hasil pengelompokan yang semakin baik (optimal). Penentuan metode terbaik menggunakan koefisien korelasi Cophenetic.

\section{Hasil dan Pembahasan}

\subsection{Gambaran Umum Perekonomian Provinsi di Indonesia}

Gambar 1a menunjukkan bahwa provinsi dengan TPT paling rendah yaitu Provinsi Bali sebesar 1,21\% sedangkan provinsi dengan TPT paling tinggi yaitu Provinsi Banten sebesar 8,01\%. Secara rata-rata, TPT provinsi di Indonesia sebesar 4,52\%. Kemudian, berdasarkan Gambar 1b dapat diketahui provinsi dengan Upah Minimum Provinsi (UMP) paling rendah yaitu Provinsi Banten sebesar Rp 1.704.607,sedangkan provinsi dengan UMP paling tinggi yaitu Provinsi DKI Jakarta pada angka 
Rp 4.276.349,-. Secara rata-rata, UMP di Indonesia ialah sebesar Rp 2.664.186,62. Provinsi dengan Persentase Penduduk Miskin (PPM) paling rendah berdasarkan Gambar 1c yaitu Provinsi Bali sebesar 3,78\% sedangkan provinsi dengan PPM paling tinggi yaitu Provinsi Papua sebesar 26,64\%. Secara rata-rata, PPM provinsi di Indonesia sebesar $10,43 \%$. Selain itu, dapat diketahui pula provinsi dengan Tingkat Penghunian Hotel (TPH) paling rendah yaitu Provinsi Bali sebesar 2,57\% sedangkan provinsi dengan TPH paling tinggi yaitu Provinsi DKI Jakarta sebesar 41,03\% berdasarkan Gambar 1d.

\subsection{Analisis Cluster Berdasarkan Faktor Penentu Perekonomian di Indonesia}

Analisis cluster dalam penelitian ini digunakan untuk mengelompokkan provinsiprovinsi di Indonesia berdasarkan faktor penentu perekonomian yang telah dipilih oleh peneliti di atas. Pendekatan yang dipilih dalam melakukan analisis cluster ini ialah secara hierarki karena diasumsikan bahwa banyak cluster yang akan terbentuk tidak diketahui. Metode yang dipilih adalah metode cluster hierarki yang dapat memberikan hasil dengan akurasi terbaik. Oleh karena itu, analisis dilakukan dengan menggunakan lima metode hierarki, yaitu Average, Single, Complete, dan Centroid Linkage, serta Ward. Selanjutnya hasil pengelompokan kelima metode akan dibandingkan dan dipilih metode dengan tingkat akurasi yang paling besar.

Langkah pertama yang dilakukan ialah mengukur kemiripan provinsi-provinsi di Indonesia. Jarak Euclidean dipilih sebagai ukuran jarak. Semakin kecil jarak Euclidean sepasang provinsi, maka karakteristik kedua provinsi tersebut semakin mirip atau hampir sama.

Tahap selanjutnya, yaitu menentukan banyaknya cluster yang paling optimal dalam mengelompokkan provinsi-provinsi di Indonesia. Pada penelitian ini, ditentukan banyaknya cluster yang dalam pengelompokan yaitu, antara 2 hingga 5 cluster. Dalam menentukan banyaknya cluster yang paling optimal, digunakan tiga aturan indeks validitas cluster, yaitu indeks Dunn, Connectivity, dan Silhoutte. Hasil penentuan banyaknya cluster yang paling optimal berdasarkan indeks validitas cluster tersaji pada Tabel 1.

Tabel 1: Indeks Validitas tiap Banyaknya Cluster

\begin{tabular}{ccccc}
\hline \multirow{2}{*}{ Indeks Validitas } & \multicolumn{4}{c}{ Banyaknya Cluster } \\
\cline { 2 - 5 } & 2 & 3 & 4 & 5 \\
\hline Connectivity & 3,0956 & 6,0246 & 9,4536 & 16,6611 \\
Dunn & 0,4046 & 0,4041 & 0,2369 & 0,2894 \\
Silhouette & 0,3531 & 0,2531 & 0,1720 & 0,1814 \\
\hline
\end{tabular}




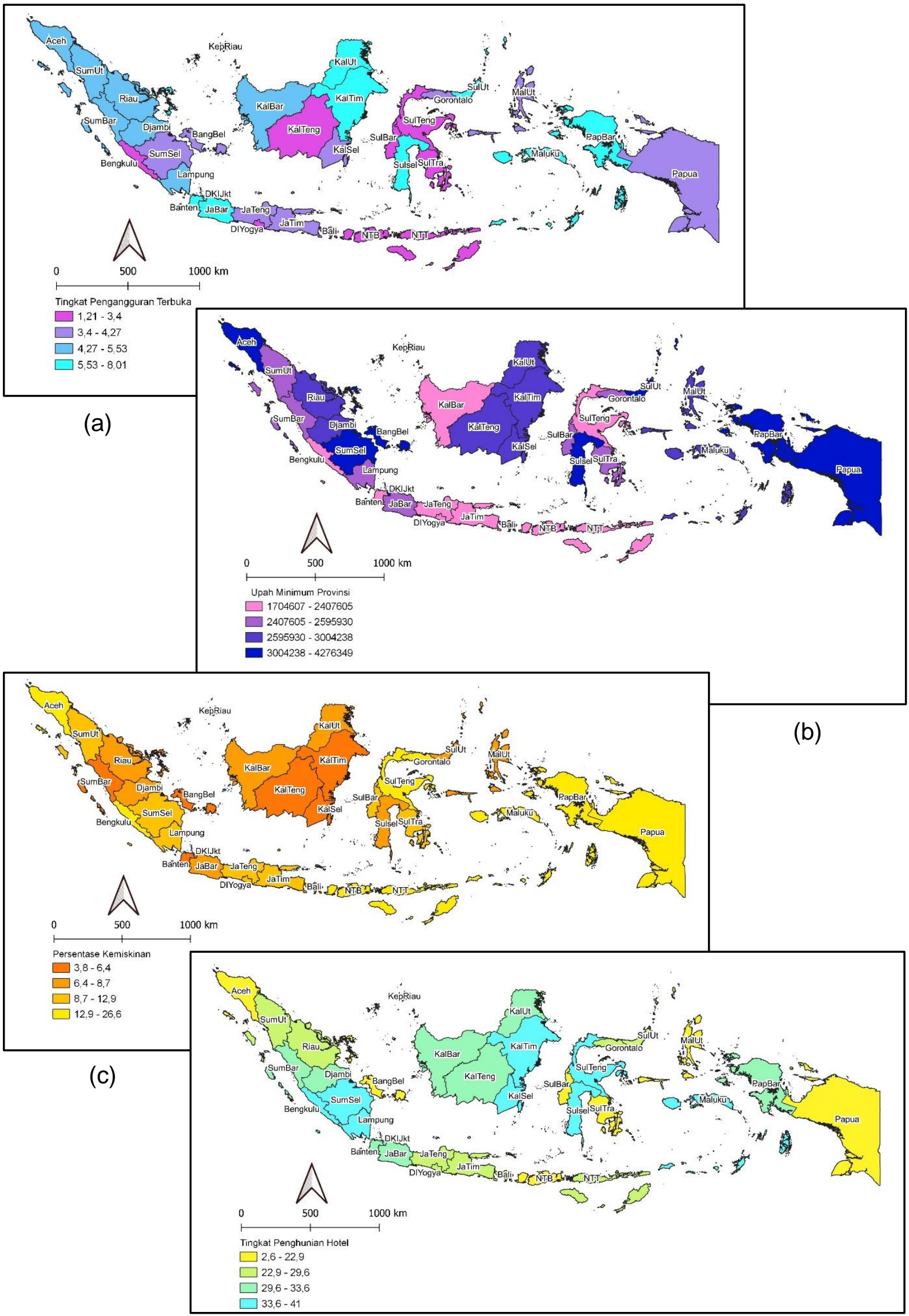

(d)

Gambar 1: Peta Distribusi Perekonomian Provinsi di Indonesia Tahun 2020

Semester 1. (a) TPT; (b) UMP; (c) PPM; (d) TPH 
Pada indeks Connectivity, nilai indeks yang semakin rendah menunjukkan banyaknya cluster yang semakin baik. Oleh karena itu, menurut indeks ini dua cluster dipilih sebagai banyak cluster optimal. Sedangkan pada indeks Dunn, nilai indeks yang semakin tinggi menunjukkan banyaknya cluster yang semakin baik. Oleh karena itu, menurut indeks ini dua cluster dipilih sebagai banyak cluster optimal. Lalu pada indeks Silhouette, nilai indeks yang semakin tinggi menunjukkan banyaknya cluster yang semakin baik sama seperti indeks Dunn. Oleh karena itu, menurut indeks ini dua cluster dipilih sebagai banyak cluster optimal. Dari hasil ketiga indeks validitas, dapat dilihat bahwa ketiga indeks memberikan hasil keputusan yang sama, yaitu dua cluster merupakan banyaknya cluster yang paling optimal dalam mengelompokkan provinsiprovinsi di Indonesia.

Setelah menentukan banyak cluster optimal, langkah selanjutnya ialah mengelompokkan provinsi-provinsi yang memiliki karakteristik sama ke dalam suatu cluster. Pengelompokan dapat dilakukan dengan bantuan diagram dendogram yang proses pembentukannya dilakukan dengan metode cluster hierarki, yaitu metode Average, Single, Complete, dan Centroid Linkage, serta Ward. Setelah diagram terbentuk, dilakukan pemotongan dendogram sehingga menghasilkan dua cluster, sesuai dengan banyaknya cluster optimal.

Koefisien korelasi Cophenetic (rCoph) digunakan untuk mengukur validitas hasil analisis cluster. Nilai rCoph berada pada rentang -1 dan 1, dimana $r$ Coph yang semakin mendekati 1 menunjukkan bahwa hasil analisis yang diperoleh dari proses pengelompokan semakin akurat. Hasil penentuan metode cluster yang terbaik berdasarkan rCoph dapat dilihat pada Tabel 2.

Tabel 2: Koefisien Korelasi Cophenetic

\begin{tabular}{cc}
\hline Metode Cluster & Koefisien Korelasi Cophenetic \\
\hline Average Linkage & 0,7644 \\
Single Linkage & 0,7225 \\
Complete Linkage & 0,5901 \\
Centroid Linkage & 0,7457 \\
Ward & 0,5477 \\
\hline
\end{tabular}

Berdasarkan Tabel 2, dapat diketahui bahwa metode Average Linkage memiliki koefisien korelasi Cophenetic tertinggi yaitu sebesar 0.7644. Oleh karena itu, disimpulkan bahwa metode cluster terbaik dalam kasus ini adalah metode Average Linkage dengan cluster sebanyak dua yang merupakan banyak cluster optimal. Secara rinci, anggota dari masing-masing cluster provinsi yang terbentuk tersaji pada Gambar 2.

Berdasarkan Gambar 2 dapat dilihat bahwa cluster dua merupakan cluster yang beranggotakan Provinsi Papua, sedangkan cluster satu terdiri dari 33 provinsi di Indonesia lainnya.

\subsection{Identifikasi Karakteristik Cluster Pengelompokan Provinsi di Indonesia}

Tabel 3 menunjukkan bahwa provinsi-provinsi pada cluster pertama ialah provinsi dengan Persentase Penduduk Miskin (PPM) dan Upah Minimum Provinsi (UMP) yang lebih rendah daripada provinsi pada cluster kedua. Sedangkan Tingkat Pengangguran 
Terbuka (TPT) dan Tingkat Penghunian Hotel (TPH) pada provinsi-provinsi cluster pertama cenderung lebih besar daripada provinsi pada cluster kedua. Oleh karena itu,



Gambar 2: Peta Hasil Pengelompokkan (clustering)

Tabel 3: Rata-Rata Cluster Hasil Pengelompokan Provinsi di Indonesia

\begin{tabular}{ccc}
\hline \multirow{2}{*}{ Variabel } & \multicolumn{2}{c}{ Cluster } \\
\cline { 2 - 3 } & 1 & 2 \\
\hline Persentase Penduduk Miskin (\%) & 9,94 & 26,64 \\
Tingkat Pengangguran Terbuka (\%) & 4,55 & 3,62 \\
Upah Minimum Provinsi (rupiah) & $2.638 .352,88$ & 3.516 .700 \\
Tingkat Penghunian Hotel (\%) & 28,31 & 17,49 \\
\hline
\end{tabular}

Tabel 4: Data BPS Tahun 2019

\begin{tabular}{clcl}
\hline No. & \multicolumn{1}{c}{ Indikator } & Papua & Tertinggi di Indonesia \\
\hline 1. & Persentase Kemiskinan (\%) & 4,47 & 14,9 (NTB) \\
2. & Jumlah Penduduk Miskin (Ribu Jiwa) & 43,63 & 2725,91 (Jawa barat) \\
3. & Jumlah Tamu Asing pada Hotel & 12,58 & $5.687,80$ (Bali) \\
& Bintang (Ribu Orang) & & \\
4. & Jumlah Tamu Asing pada Hotel Non & 2.557 & 2.462 .937 (Bali) \\
& Bintang (Orang) & 0,14 & 0,58 (Bengkulu) \\
5. & Indeks Keparahan Kemiskinan & 52.081 .723 \\
6. & Jumlah Perjalanan Wisatawan & 796.440 & $\begin{array}{l}52.03 w a \text { Timur) } \\
\text { (Jawantara (Orang) }\end{array}$ \\
\hline
\end{tabular}

hal ini mengindikasikan bahwa cluster pertama memiliki perekonomian yang lebih terdampak Covid-19 dibandingkan dengan cluster kedua.

Dengan kata lain, Papua sebagai satu-satunya anggota pada cluster kedua merupakan provinsi pencilan dengan karakteristik yang paling berbeda dari provinsiprovinsi lainnya di Indonesia. Penentuan Papua sebagai provinsi dengan tingkat perekonomian terdampak rendah didukung oleh data pada Tabel 5.

Berdasarkan indikator-indikator kemiskinan pada Tabel 4, dapat diketahui bahwa 
Papua bukan merupakan provinsi dengan kemiskinan terendah, meskipun Indeks Pembangunan Manusia (IPM) yang dimiliki Papua adalah terendah di Indonesia yaitu sebesar 60.84. Kesimpulan dari indicator-indikator ini menunjukkan bahwa hanya sebagian kecil dari masyarakat Papua yang berada dalam kategori miskin, sehingga perekonomian Papua masih cukup stabil meskipun pandemi Covid-19 melanda Indonesia. Sejalan dengan itu, De Fretes (2017) menyatakan bahwa Papua merupakan provinsi yang memiliki pertumbuhan tinggi hingga di atas rata-rata pertumbuhan ekonomi nasional. Bahkan ketika Covid-19 melanda pada tahun 2020, laju pertumbuhan Produk Domestik Regional Bruto (PDRB) mencapai angka 2.23\% sedangkan Produk Domestik Bruto (PDB) nasional jatuh ke angka $-2.07 \%$. Menurut Rosyid dkk (2020), sektor pertambangan memiliki peran yang sangat besar pada perkembangan ekonomi di Papua. Sektor tersebut memiliki investasi yang besar juga produktivitas per tenaga kerja yang tinggi.

Jumlah tamu asing dan jumlah perjalanan wisatawan nusantara menunjukkan seberapa banyak orang dari luar Papua yang datang ke Papua pada tahun 2019. Dapat dilihat bahwa Papua berada pada angka yang sangat rendah dibandingkan dengan provinsi dengan angka tertinggi pada indikator tersebut. Sehingga dapat disimpulkan, tidak banyak orang asing yang datang ke Papua dibandingkan provinsiprovinsi lain di Indonesia. Dengan kata lain, Papua memiliki resiko yang rendah terjadi penyebaran Covid-19 dibandingkan dengan provinsi lainnya. Hasil ini sejalan dengan hasil penelitian Alwandi \& Muchlisoh (2020) yang menyatakan bahwa Papua adalah satu-satunya provinsi yang memiliki karakteristik berbeda dari provinsi-provinsi lain. Dengan danya Covid-19, provinsi lain mengalami kontraksi laju pertumbuhan ekonomi, sedangkan Papua berhasil tumbuh $4.52 \%$ karena peningkatan pertambangan dan penggalian karena naiknya emas dan tembaga PT. Freeport pada periode triwulan II2020.

Selain itu, dikeluarkannya kebijakan pemerintah yang berhubungan dengan penutupan pariwisata dan penginapan serta akses transportasi seperti bandara, stasiun kereta api, dan lain-lain tidak beresiko tinggi mempengaruhi perekonomian di Provinsi Papua. Sebaliknya, provinsi-provinsi pada cluster pertama memiliki TPH yang tinggi sehingga sektor perhotelan ini sangat berkontribusi pada perekonomian provinsi. Dengan adanya Covid-19, sejak akhir Januari 2020 pemerintah membatasi pergerakan manusia lintas negara yang berakibat menurunnya tingkat kunjungan wisman. Peraturan ini akan beresiko menurunkan angka jumlah pengunjung hotel sehingga pendapatan dari sektor hotel akan berkurang. Hal ini diperparah dengan peraturan agar sejumlah hotel atau penginapan berhenti beroperasi untuk menurunkan tingkat penyebaran Covid-19. Di Bali saja, hingga 7 April 2020 sebanyak 281 hotel atau sekitar 55\% dari jumlah hotel di Bali ditutup karena adanya Covid-19 (Kusuma et al., 2021). Hal ini akan berdampak pada perekonomian di cluster pertama, mengingat perhotelan adalah salah satu sektor yang mendukung perekonomian provinsi-provinsi di cluster tersebut. Oleh karena itu, berdasarkan karakteristik ini cluster pertama disimpulkan lebih terdampak Covid-19.

Hasil penelitian ini dapat menjadi pertimbangan pemerintah dalam merumuskan kebijakan pemulihan ekonomi. Pemerintah dapat mengeneralisir kebijakan pemulihan ekonomi akibat Covid-19 karena pandemi ini memberikan tingkat dampak yang sama terhadap hampir seluruh perekonomian provinsi di Indonesia. 


\section{Simpulan dan Saran}

Dari hasil analisis dan pembahasan yang dilakukan terhadap sektor yang menunjang perekonomian di Indonesia didapatkan kesimpulan bahwa analisis cluster dengan menggunakan beberapa metode linkage, menunjukkan bahwa metode Average memiliki pengelompokan yang teliti dan memiliki nilai koefiseien korelasi cophenetic yang lebih tinggi dibandinggkan metode lainnya. Dengan cluster 1 perekonomian daerah yang sangat terdampak Covid-19 yaitu 33 Provinsi di Indonesia kecuali Papua, cluster 2 perekonomian daerah yang kurang terdampak Covid-19 yaitu Provinsi Papua. Berdarkan hasil Covid-19 sangat berdampak pada perekonomian di seluruh Provinsi di Indonesia kecuali Papua. Oleh karena itu pemerintah di Indonesia dapat mempertimbangkan hasil penelitian ini untuk mengeneralisir keputusan dalam usaha pemulihan perekonomian Indonesia. Usaha yang dilakukan dapat dalam bentuk pemberian dana UMKM (Usaha Mikro, Kecil dan Menengah), mengurangi tingkat pengangguran pada industri atau perusahaan yang dilakukan secara WFH (Work From Home) serta membuka pariwisata dan penginapan sesuai dengan protocol dengan ketak untuk mengurangi penyebaran Covid-19 serta dapat memulihkan perekonomian di Provinsi di Indonesia

\section{Daftar Pustaka}

Alwandi, M. A., \& Muchlisoh, S. (2020). Karakteristik Pertumbuhan Ekonomi dan Sektor Basis Provinsi di Indonesia pada Masa Pandemi Covid-19. Seminar Nasional Official Statistics, 2020(1): 82-90. https://doi.org/10.34123/semnasoffstat.v2020i1.516

De Fretes, P. N. (2017). Analisis Sektor Unggulan (LQ), Struktur Ekonomi (Shift Share), dan Proyeksi Produk Domestik Regional Bruto Provinsi Papua 2018. Develop, 1(2). https://doi.org/10.25139/dev.v1i2.384

Engkus, E., Suparman, N., Tri Sakti, F., \& Saeful Anwar, H. (2020). Covid-19: Kebijakan mitigasi penyebaran dan dampak sosial ekonomi di Indonesia. LP2M. Retrieved from http://digilib.uinsgd.ac.id/30820/

Hair, J., Black, W. C., Babin, B. J., \& Anderson, R. E. (2010). Multivariate Data Analysis (7th ed.). London: Pearson Education, Inc.

Halim, N. N., \& Widodo, E. (2017). Clustering Dampak Gempa Bumi di Indonesia Menggunakan Kohonen Self Organizing Maps (SOM). Prosiding SI MaNls (Seminar Nasional Integrasi Matematika Dan Nilai-Nilai Islami), 1(1): 188-194.

Hardilawati, W. laura. (2020). Strategi Bertahan UMKM di Tengah Pandemi Covid-19. Jurnal Akuntansi Dan Ekonomika, 10(1): 89-98. https://doi.org/10.37859/jae.v10i1.1934

Imanto, R., Panorama, M., \& Sumantri, R. (2020). Pengaruh Pengangguran dan Kemiskinan terhadap Pertumbuhan Ekonomi di Provinsi Sumatera Selatan. AlInfaq: Jurnal Ekonomi Islam, 11(2): 118-139. https://doi.org/10.32507/ajei.v11i2.636

Johnson, R. A., \& Wichern, D. W. (2007). Applied Multivariate Statistical Analysis (6th ed.). London: Pearson Education, Inc. 
Julianto, F. T., \& Suparno. (2016). Analisis Pengaruh Jumlah Industri Besar dan Upah Minimum terhadap Pertumbuhan Ekonomi di Kota Surabaya. JEB17: Jurnal Ekonomi Dan Bisnis, 1(02). https://doi.org/10.1234/jeb17.v1i02.914

KemLu. (2020). Kebijakan Pemerintah Republik Indonesia Terkait Wabah Covid-19. Retrieved March 25, 2021, from Kedutaan Besar Republik Indonesia di Brussels, Belgia website: https://kemlu.go.id/brussels/id/news/6349/kebijakanpemerintah-republik-indonesia-terkait-wabah-covid-19

Kovács, F., Legány, C., \& Babos, A. (2006). Cluster validity measurement techniques. Proceedings of the 5th WSEAS International Conference on Artificial Intelligence, Knowledge Engineering and Data Bases.

Kurniawansyah, H., Amrullah, A., Salahuddin, M., Muslim, M., \& Nurhidayati, S. (2020). Konsep Kebijakan Strategis dalam Menangani Eksternalitas Ekonomi dari Covid - 19 pada Masyarakat Rentan di Indonesia. Indonesian Journal of Social Sciences and Humanities, 1(2): 130-139.

Kusuma, B., Wijaya, B. K., \& Mariani, W. E. (2021). Dampak Pandemi Covid-19 pada Sektor Perhotelan di Bali. Warmadewa Management and Business Journal (WMBJ), $\quad 3(1)$. Retrieved from https://www.ejournal.warmadewa.ac.id/index.php/wmbj/article/view/3007

Mattjik, A. A., \& Sumertajaya, I. M. (2011). Sidik Peubah Ganda dengan Menggunakan SAS. Bogor: IPB Press.

Novriansyah, M. A. (2018). Pengaruh Pengangguran dan Kemiskinan Terhadap Pertumbuhan Ekonomi di Provinsi Gorontalo. Gorontalo Development Review, 1(1): 59-73. https://doi.org/10.32662/golder.v1i1.115

Our World in Data. (2020). Coronavirus Pandemic (COVID-19) - the data - Statistics and Research. Retrieved March 25, 2021, from https://ourworldindata.org/coronavirus-data

Rosyid, F. A., Ginting, F. A., \& Wibowo, A. P. (2020). Analisis Dampak Investasi terhadap Perekonomian Daerah: Studi Kasus Investasi Pertambanga Mineral Logam Provinsi Papua. Indonesian Mining Professionals Journal, 2(1): 11-28. https://doi.org/10.36986/impj.v2i1.18

Steven, H. (2020). Why Outbreaks like Coronavirus Spread Exponentially, and How to "Flatten the Curve." Retrieved March 25, 2021, from The Washington Post website: https://www.washingtonpost.com/graphics/2020/world/coronasimulator/?fbclid=IwAR0KWRel9vtrX0BvzEssTdr3GuhEuytyt42HPrF8BjOJGiV Ndc0s9rFcn4U\&utm_source=reddit.com

Suastika, I. G. Y., \& Yasa, I. N. M. (2017). Pengaruh Jumlah Kunjungan Wisatawan, Lama Tinggal Wisatawan dan Tingkat Hunian Hotel Terhadap Pendapatan Asli Daerah dan Kesejahteraan Masyarakat Pada Kabupaten/Kota di Provinsi Bali | E-Jurnal Ekonomi Pembangunan Universitas Udayana. E Jurnal Ekonomi Pembangunan, 6(7): 1157-1394.

Syafrida, S., \& Hartati, R. (2020). Bersama Melawan Virus Covid 19 di Indonesia. SALAM: Jurnal Sosial Dan Budaya Syar-i, 7(6): 495-508. https://doi.org/10.15408/sjsbs.v7i6.15325

Ulya, H. N. (2020). Alternatif Strategi Penanganan Dampak Ekonomi Covid-19 Pemerintah Daerah Jawa Timur Pada Kawasan Agropolitan. El-Barka: Journal of Islamic Economics and Business, 3(1): 80-109. https://doi.org/10.21154/elbarka.v3i1.2018 